\title{
LIGHT AS A FACTOR IN THE REGENERATION OF HYDROIDS
}

\author{
SECOND STUDY
}

A. J. GOLDFARB

Zoölogical Laboratory, Columbia University, New York

Three different kinds of hydroids are found abundantly in the harbor of Woods Hole, Mass. Of these Tubularia (Parypha) crocea reaches its most luxuriant growth about the end of June and then declines in numbers and vitality toward the end of July or the first part of August, at which time they disappear completely. In the meantime Eudendrium ramosum begins to grow about the first part of July, reaches its maximum growth about the end of July and then gradually disappears. Pennaria tiarella comes last, toward the end of July, and persists until the beginning of September. All three kinds may be found on the same piles at the same time.

In a previous publication ${ }^{1}$ the curious effect of light upon the regeneration of $\mathrm{E}$. ramosum was described. From those studies it was evident that the idea of the simple and direct effect described by Loeb, ${ }^{2}$ needed radical revision. In brief the facts for $E$. ramosum are as follows. Under ordinary conditions, hydranths are replaced in about 48 hours. As the hydranths live only a few days, they are replaced again and again by new ones. If the number produced on successive days be examined, it is found that the largest number are regenerated within a few days after their removal, and that the number steadily decreases on succeeding

${ }^{1}$ Goldfarb, A. J. Experimental Study of Light as a Factor in the Regeneration of Hydroids. Journ. Exp. Zoöl., vol. 3, 1905.

${ }^{2}$ Loeb, J. The Influence of Light on the Development of Organs in Animals. Pfüger's Archiv., Bd. 63, 1895 .

THE JOURNAI OF EXPERIMENTAL ZOOLOGY, voL. 8, No. 2. 
days, until about the $13^{\text {th }}$ day, after which no more hydranths are produced.

When these colonies were removed to a dark chamber, dark enough not to effect photographic plates, the number of hydranths produced in this chamber, and the rate of their development, was not materially altered. Regeneration took place in the dark as well, or almost as well, as in the light. But this statement holds true only during the first cycles. For, after this period a profound change occurred, as a result of which these hydroids did not regenerate a single hydranth so long as they were kept in the dark. This treatment rendered them remarkably responsive to light, so that exposure always induced the regeneration of hydranths. But the surprising feature was the intense sensitiveness which hydroids so treated seemed to possess. Exposure to shaded light of 15 seconds sufficed to stimulate the regeneration of a whole series of hydranths.

No explanation of this peculiar relation to light was given. It cannot be said that $E$. ramosum is dependent upon light by virtue of substances produced by symbiotically associated organisms. Nor is it dependent directly upon light for its sustenance in the manner of plants.

The following experiments were undertaken with the idea of finding what influence light has upon the regeneration of the other two closely associated hydroids, to ascertain whether this extreme sensitiveness to light is common to the other forms, and possibly to determine what significance this fact has in the life history of these plant-like animals4.

The procedure was practically the same in all the experiments. The hydranths were removed from the selected stalks and the same number were placed in wide shallow dishes containing the same quantity of sea-water. To prevent the rapid accumulation of bacteria, the water was changed at first daily, and in the later experiments, on alternate days. The controls were kept in the shaded light of the laboratory, the others were prepared, in the

\footnotetext{
${ }^{3}$ Vide Journ. Exp. Zool. Vol. 3, 1905.

The experiments were made at the Marine Biological Laboratory, Woods Hole, Mass. For the privilege of working therein I am indebted to the Director, Prof. F. R. Lillie.
} 
manner just described, and kept in a dark chamber. The manipulation, change of water and counting of hydranths of the latter stalks were all done in the dark room, into which the only light was that which came through a double thickness of ruby glass. The temperature of the controls varied slightly from the others, the difference never exceeding 2 to $21^{\circ} \mathrm{C}$. As each new hydranth was fully developed it was removed. Thus the figures in the tables represent the actual number of regenerated hydranths.

\section{TUBULARIA（PARYPHA） CROCEA}

This is a colonial hydroid usually made up of unbranched stalks, though not infrequently small branches are developed. Stalks were cut off quite close to their bases, their hydranths were then removed at approximately the same level for all the stalks of a series, i. e., either at the base of the hydranth or the middle of the stalk, etc. The results obtained among the controls and among those maintained in the dark chamber are given in the accompanying table.

In Experiment I, the hydranths were removed about fiveeighths inch from the apical ends. No branching stalks were used. The 24 controls were prepared in the light, 40 others were prepared and kept in the dark. In Experiment 2, there were 20 controls, and 42 in the dark. In Experiments 3 and 4 , all hydranths were removed in the light. In Experiment 3 , there were 20 controls, 60 in the dark. In Experiment 4, the hydranths only were removed, leaving one part of a colony of about 50 stalks, connected at their bases, to serve as a control, and another part of the colony was placed in the dark. In all there were I I 4 controls and $I 92$ in the dark.

As in E. ramosum, the hydranths are regenerated ordinarily within two days after their removal. In the dark, their first appearance was somewhat delayed, though all subsequent regeneration took place at the normal rate. This initial retardation is seen in Experiment I, where 24 controls regenerated 2. I hydranths on the second day and I on the third day. The $40 \mathrm{kept}$ in the dark regenerated 5 on the second day, while 23 appeared on 
TABLE I

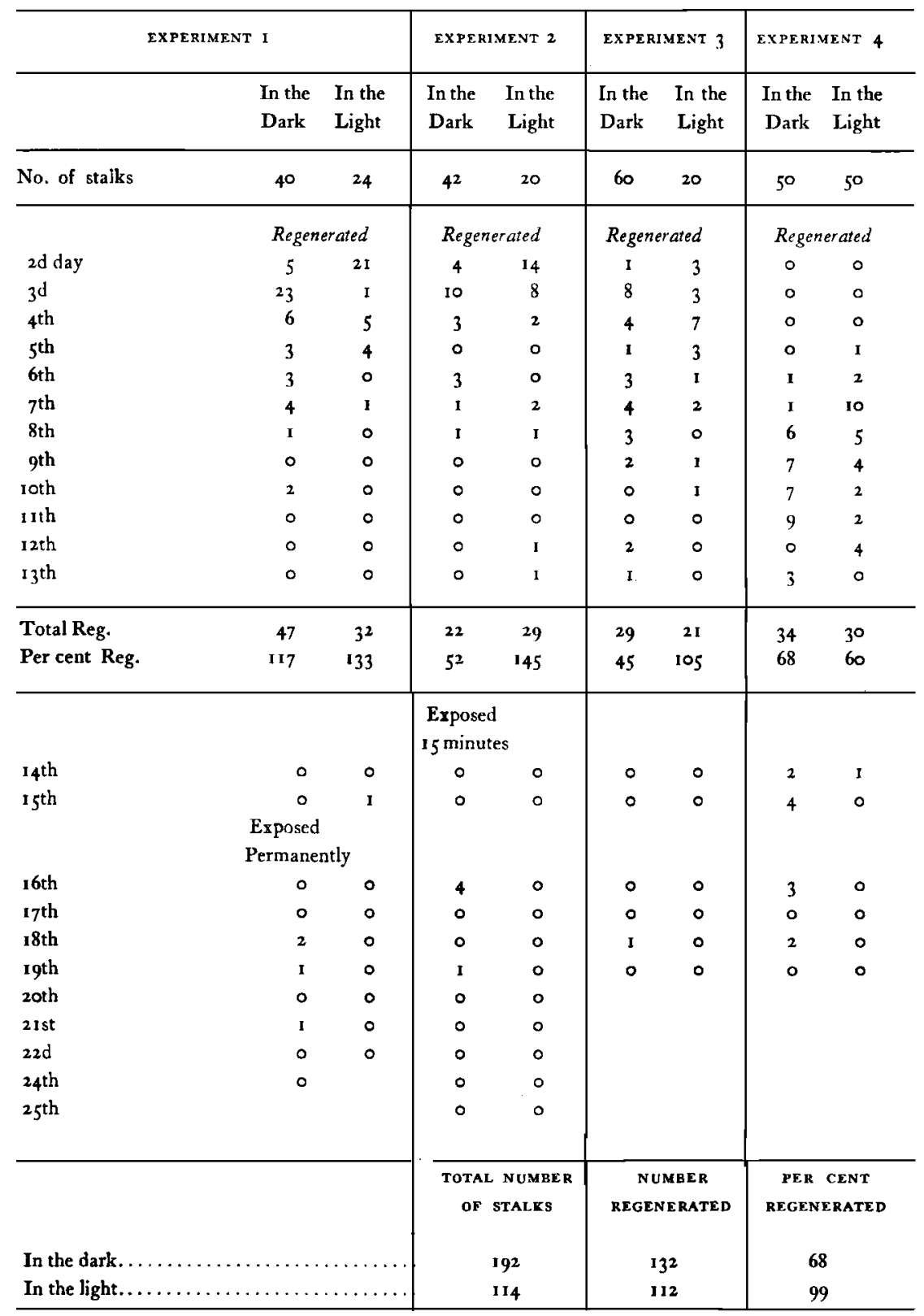


the third day. In Experiment 2, 20 controls regenerated 14 and 8 hydranths on the second and third days respectively, while 42 , in the dark, regenerated 4 on the second and 10 on the third day. The same relation obtains in Experiment 3. In Experiment 4, $5^{\circ}$ controls regenerated I, 2, IO, 5, 4, and 2 hydranths on the $5^{\text {th, }}$ 6 th, 7 th, 8th, 9th and Ioth days respectively, while the $5^{\circ}$ in the dark regenerated $0, I, I, 6,7$, and 7 hydranths in the same time.

The curve representing the number of hydranths regenerated on successive days, are analogous and that given for Eudendrium. The maximum number produced at any one time appeared within a few days after the beginning of the experiment, and the number steadily decreased on the following days until no more were produced. In Experiment 3, no more hydranths appeared after the Ioth day, in Experiment 2, after the $13^{\text {th }}$ day, in Experiment 4, after the I $4^{\text {th }}$ day, and in Experiment I, after the I $5^{\text {th }}$ day. Though the observations were continued for over 25 days the controls no longer produced any hydranths. In this respect Tubularia crocea behaves exactly like Eudendrium.

While the controls no longer regenerated after $7,10,1_{3}$ and I 4 days respectively, those kept in the dark produced new hydranths during 10, I3, 8 and I 7 days for the corresponding series. This difference in time, namely, 3 days, was much greater than the initial retardation. This may be interpreted to mean that the prolonged darkness continued to retard the development of the hydranths.

Beside this retardation, the removal of light also inhibits development to a considerable degree. Even during the first cycle, while the number of hydranths that were regenerated was large, the maximum (maximum per cent rather than the absolute number is here referred to), for any one day was always less than among the corresponding controls. Also the total per cent regenerated during a definite period, I3 days for example, was about 3 I per cent less in the dark, than in the light. Darkness then exerts certain definite and measureable effects even during the first period or cycle, and in these respects the behavior of this hydroid is not unlike that of Eudendrium.

But it is only after this first cycle, that the stalks kept in the dark 
come to differ so radically from the controls. The latter by this time were quite spent, i. e., they no longer produced hydranths in the light. Those in the dark, likewise produced no more hydranths but upon exposure to light not a single but a series of hydranths were regenerated. In Experiment I, and 2, 4 and 5 hydranths, respectively, were regenerated in this manner. An exposure of but 15 minutes sufficed to stimulate the production of several hydranths. In this respect also Tubularia closely resembles Eudendrium, though the latter was far more sensitive to light, as shown by the larger number of hydranths regenerated after exposures, by the longer regenerating period, and by the briefer light stimulus that sufficed to bring these about.

There are two minor points that may be mentioned at this place. (I) Individual records made it quite certain that stalks kept in the dark could regenerate a second and third time. Colonies whose stalks had been separated behaved in exactly the same manner as those that were not so separated from the colony.

The experiments were drawn to a close by the lateness of the season, when good healthy stalks were no more to be procured. It would have been interesting to have ascertained with far more exactness the minimal exposure that would have stimulated a regenerative cycle, to have ascertained whether a second or third cycle could have been induced by such brief or briefer exposures.

But the facts, so far as they go, clearly indicate that Tubularia crocea behaves essentially like Eudendrium. During the first cycle, regeneration takes place in the dark almost as well as in the light; that after this period regeneration occurs only after the stalks are exposed to the light. The two hydroids differ in that longer exposures are required to stimulate Tubularia, and that fewer hydranths result from such stimulation; in other words Tubularia is less sensitive to light than Eudendrium. The uniformity of the results in the four experiments bespeaks the correctness of these conclusions. 
It has been already pointed out that this hydroid lives with $T$. crocea and $E$. ramosum on the same piles and at the same sea level. Like Eudendrium, it is very much branched, and experiments showed that the regeneration of similar pieces from these two hydroids gave practically the same results.

New hydranths were regenerated in about 48 hours after their removal, and in this regard resembled the other two hydroids. These newly formed hydranths were removed daily, so that the figures actually represent the number of different hydranths regenerated.

There is one disturbing factor that has to be reckoned with, namely, the tendency to produce "roots" in place of hydranths particularly after thigmotactic stimuli, such as contact with the side of the dish, or with other stems. In as much as the size of the stalks, of the dishes, the number of stalks in each dish and other conditions were quite the same among the controls and among those in the dark, this disturbing factor may be fairly assumed to be constant in both sets of stalks. In some colonies this tendency to root formation is so strong that nearly all cut ends produced roots instead of hydranths.

The regeneration of Pennaria differs from the other two hydroids in several respects. In the first place, the curve represented by the number of new hydranths on successive days, was not so definite as in Tubularia or Eudendrium, due in all probability to the tendency to heteromorphic "root" formation. Yet the curve of Pennaria approximated very closely that of the other two hydroids. This is shown as follows. The maximum number of hydranths produced on any one day, appeared during the early part of the experiment, and if continued for a long period the number towards the close of the experiment was always very small; and these hydroids, it might be added, were decidedly smaller, i. e., one-half to one-third the normal size. In Experiment 5 , the number produced on the $2 \mathrm{~d}$ to the 6 th days inclusive, was I2, 15, 16, I3, I I hydranths. During succeeding 5 day intervals, the greatest number that appeared on any one day was 
13, 8, 4 and 2. Greater irregularities took place in Experiments 6 and 7. In Experiment 6,8 was the largest number of hydranths present at one time during the first 5 days and during succeeding 5 day intervals the largest number was $14,17,9$, 10, 5, I3, and 5 hydranths. In Experiment 7, the figures for the same intervals were 10, 10, and 7 hydranths.

In the second place, new hydranths were regenerated during a longer cycle than either of the other two hydroids, 23 days in Experiment 7, 26 days in Experiment 5, and 35 days in Experiment 6 , and would in all probability have continued to regenerate for a longer period. After so protracted an interval the hydranths were not only fewer as mentioned above but were decidedly smaller or malformed.

The most decided difference was observed in the behavior of those stalks that were placed in the dark. From the first not a single hydranth was regenerated from these stalks. Although a little over one thousand branchlets and pedicels from various colonies were placed in the dark, in no instance was a hydranth produced. Pennaria unlike Tubularia and Eudendrium requires no preliminary treatment in order to bring about a total cessation of the regenerative processes.

As might have been anticipated, the stalks in the dark required particularly long exposures in order to stimulate the formation of new hydranths. Exposures of 2 minutes and 5 minutes (Experiment 5) proved totally inefficient. Exposures of 3, 5, 8, 10, I 5 , $20,25,30$, and even 60 minutes (Experiment 6) were equally inadequate, even though the exposures were made in the direct rays of the sun. Exposures of 2 hours, 3 hours and 4 hours were sometimes ineffective and sometimes produced hydranths. In Experiment 6, for example, 200 pedicels exposed for 2 hours regenerated during the next five days only 4 hydranths, while the controls regenerated 70 hydranths in the same time. Exposures of 3 and 4 hours gave no better results than the 2 hour exposures. The hydranths so produced were frequently dwarfed. The minimal time required to stimulate regeneration could be still further reduced, in some colonies, by the simple expedient of exposing the hydroids daily. Instead of two or more hour exposures, regenera- 
tion could be induced with far more certainty by exposures of one hour or one-half hour for several successive days. And although very few hydranths were produced at any one time they appeared on as many as 5 separate days. Thus, daily half hour exposures resulted in $0,0,3,6,0$, hydranths in one set of stalks and 0,0 , $\mathrm{I}, \mathrm{I}, \mathrm{I}, O$ in another set. One hour exposures daily gave rise to $0,0,0, \mathrm{I}, \mathrm{I}, \mathrm{O}$ and $\mathrm{O}, \mathrm{O}, \mathrm{O}, 4, \mathrm{O}, \mathrm{O}$, and $\mathrm{O}, 0,2, \mathrm{I}, 2,2$ hydranths in 3 different sets of stalks.

If left in the light for a whole day, hydranths were almost certain to appear in every experiment and these were large and numerous. Though the absence of light was inimical to development yet no permanent injury resulted from prolonged retention in the dark. For on returning the stalks to the light many normal sized hydranths were immediately regenerated. After to days in the dark the stalks in Experiment 5, were brought into the light and produced $0, \mathrm{I}, 4,8,0,5,5, \mathrm{I}, 0,3,0,2,0,4, \mathrm{I}, 3$ hydranths during the next 16 days. In Experiment 6, after 16 days in the dark $0,14,31,26,68,17$, etc., hydranths were regenerated on successive days,

There is a variety of Pennaria that is found attached to eel grass not far from shore. This is said to belong to the same species as that found on the much more shaded piles of the wharves, though it differs from it in several respects. Some experiments were made upon this variety, to determine whether the difference in habitat was reflected in a difference in the amount of light required to stimulate regeneration. The stalks of this variety, it was found, required as a rule longer periods of exposure to stimulate the development of new hydranths. In other respects their behavior was quite the same.

Loeb $^{2}$ in his account of the regeneration of Eudendrium ramosum stated that this hydroid never regenerated in the absence of light. He undoubtedly confused Eudendrium with Pennaria tiarella. In conversation with the writer Loeb expressed the opinion that this was probably the case.

These comparative studies make it perfectly clear that so remarkable a sensitivenes as that displayed by Eudendrium (after the first cycle) finds no parallel among the other two closely 
associated hydroids. On the other hand the absence of light is not so directly preventive of hydranth formation among Tubularia and Eudendrium as in Pennaria. These hydroids living practically in the same environment agree in that after they have ceased to produce hydranths they may be stimulated to regenerate them by light and vice versa its absence retards and ultimately inhibits development. But the conditions and the degree to which light is effective varies with each hydroid. In Parypha and Eudendrium the absence of light inhibits regeneration only after a prolonged preliminary period. In Pennaria it is a coditio sine qua non from the very beginning.

\section{SUMMARY}

Light is a well defined factor in the regeneration of these hydroids, but the degree of effectiveness and the duration of the preliminary period required to render the hydroids susceptible to light stimuli varies. Eudendrium ramosum has a long preliminary cycle during which regeneration takes place in the dark almost as well as in the light. After this period, no regeneration occurs so long as stalks are maintained in the dark. A very brief stimulus, that is, an exposure to the light of 15 seconds, sufficed to call forth a series or cycle of hydranths. New series of hydranths could be produced again and again by repeated exposures. Like Eudendrium, Tubularia crocea also has a preliminary period of about 13 days during which hydranths are developed almost as well as in the light. At the expiration of this cycle, regeneration may be stimulated by exposure to the light of about 15 or more minutes. Pennaria tiarella differs from the other two hydroids in that there is no preliminary cycle. From the beginning hydranths are never regenerated in the dark. They may be stimulated to develop only by long exposures of 2 hour:; or more, or by exposures of one-half to one hour daily. 